\title{
PORE-PRESSURE PREDICTION FROM SEIMIC DATA IN PARTS OF THE ONSHORE NIGER DELTA SEDIMENTARY BASIN
}

\author{
Emujakporue Omokenu Godwin
}

Department of Physics, University of Port Harcourt, Nigeria

Received 2014-01-08; Revised 2014-01-22; Accepted 2014-03-19

\begin{abstract}
Pore pressure prediction in parts of the Onshore Niger Delta Sedimentary Basin using seismic reflection data has been carried out. The Bower's technique of velocity-to-pore pressure transform was adopted. The seismic velocities were derived from the seismic data using layer cake velocity model and were later compared with the available sonic logs velocities obtained from the area. Parameters in the velocity-to-pore pressure transform were estimated using the seismic interval velocities. The top of overpressure zone is about $3500 \mathrm{~m}$ which is in agreement with available data. The overpressure occurs within the shale rich region of the Agbada and top of Akata Formations in the basin. Comparison of the overpressure zone with available geophysical logs shows that the interval has lower bulk density, lower interval velocity and high porosity. With regard to the young age of the basin, the factors that might be responsible for the overpressure are mechanical compaction, chemical compaction and hydrocarbon generation. The results of the analysis revealed that the overpressure in the area is associated with simple rollover structures bounded by growth faults, especially the hanging walls. This method of pore pressure prediction is very useful because it helps to predict pore pressure ahead of the bit.
\end{abstract}

Keywords: Pore Pressure, Niger Delta, Seismic Velocity, Decompaction

\section{INTRODUCTION}

The Niger Delta Basin is the most prolific and economic sedimentary basin in Nigeria by the virtue of the size of petroleum accumulations, discovered and produced as well as the spatial distribution of the petroleum resources. The understanding of overpressure in the subsurface is important for drilling safety, exploration risk and reservoir depletion studies (Opara and Onuoha, 2009). Accurate pore pressure prediction is vital for successful and safe drilling of wells and the Deep- and Ultra-Deep offshore area of the Niger Delta is no exception. In the Niger Delta kicks have been observed in permeable zones within the Early Miocene shale, suggesting mud-weights have been set too low as a result of inaccurate predrill pressure prediction (O'Connor et al., 2011).

The prevention of drilling mud losses or kicks, the drilling risk assessment in connection with expected formation pressure, the casing design and so on are typical industry problems associated with prediction and estimation of pore pressure before and during exploration well drilling (Bell, 1994; Huffman, 2002a; 2002b). Pore pressure prediction is regularly conducted by oil companies in practically all pre-drill technical evaluations. Detection of overpressures before drilling is most useful as precautions can be taken and planning can be done accordingly.

There are many ways to determine pore pressure using drilling data, wireline logs and seismic data. Each method is suitable for different geologic settings and causes of overpressure. Drilling and wireline log data are obtained while the well is drilled. They cannot, therefore, be used for pre-drill pore-pressure prediction. The most widely used and proven theory is to transform seismic velocities into pore pressure data (Huffman, 2002b). The seismic reflection method is the typical geophysical surface techniques for 
predicting pre-drill pore pressures. Pore pressure can be deduced from seismic response by studying the interval velocities and it exploit the fact that overpressure intervals have lower velocities than normally pressured intervals at the same depth (Carcione and Cavallini, 2002; Dutta, 2002). Traditionally, this is based on estimating changes in interval velocities with depth. The interval velocities are extracted from the seismic data using Dix approximation from stacking velocity analysis performed on Common Mid Point (CMP) seismic data during processing.

Seismic velocities are strongly affected by compaction which in turn is also affected by changes in pore pressure. Under this assumption, seismic velocities can be used to predict variations in pore pressure regimes in areas that have not been drilled. The rock velocity is also affected by several factors which are not independent of each other including density, porosity, pore fluid type, fluid saturation, lithology and clay content. As a result, special attention deserves that not every velocity anomaly can be caused by pore pressure variations. Therefore the geological knowledge, sonic velocity, density and resistivity sensitivity to pore pressure are used as a guide to the seismic velocity analysis to avoid ambiguities in interpretation. The objective of this research is to determine the pore pressure regime of the study area from seismic velocities so that appropriate precautions might be taken during drilling operations in the area.

\subsection{Geology of the Niger Delta}

The study area is located within the coastal swamp of the Onshore Niger Delta, Nigeria (Fig. 1). The Niger Delta sedimentary basin is a product of triple junction phenomenon comprising the Gulf of Guinea, South Atlantic Ocean and Benue depression. It developed in late Jurassic along the failed arm during the separation process between South American and African plates (Short and Stauble, 1967; Whiteman, 1982). The two rift arms that followed the southwestern and south-eastern coast of Nigeria and Cameroon developed into passive continental margin of West Africa while the third arm formed the Benue Trough in the Gulf of Guinea. During the riftingprocess in the late Mesozoic, the clastic wedge gradually progrades into the Gulf of Guineaand advanced over $200 \mathrm{~km}$ southwards and broadens from less than 300 $\mathrm{km}$ to about $500 \mathrm{~km}$ (Doust and Omatsola, 1990).

The geology of the Tertiary section of the Niger Delta is divided into three Formations, representing prograding depositional facies distinguished mostly on the basis of sand-shale ratio (Kulke, 1995). They are namely Benin Formation, the Paralic Agbada Formation and Prodelta Marine Akata Formation. The Benin Formation is a continental deposit of alluvial and upper coastal plain sands. It consists predominantly of freshwater bearing massive continental sands and gavels deposited in an upper deltaic plain environment. The Benin Formation ranges in age from Eocene to Recent. The Agbada Formation underlies the Benin Formation. It consists of fluviomarine sands, siltstones and shales. The sandy parts constitute the main hydrocarbon reservoirs. The grain size of these reservoir ranges from very coarse to fine. The Akata Formation is the basal unit of the Tertiary Niger Delta complex. It is of marine origin and composed of thick shale sequences (potential source rock), turbidities sand (potential reservoirs in deep water and minor amount of clay and silt). Beginning in the Paleocene and through the Recent, the Akata Formation formed during low stands, when terrestrial organic matter and clays were transported to deep-sea water areas characterized by low energy conditions and oxygen deficiency (Stacher, 1995; Ige et al., 2011). It is the major source rock in the Niger Delta.

Most of the traps in Niger delta fields are structural although stratigraphic traps are not uncommon. The structural traps developed during synsedimentary deformation of the Agbada paralic sequence (Evamy et al., 1978; Stacher, 1995). Structural complexity increases from the north (earlier formed depobelts) to the south in response to increasing instability of the undercompacted, over-pressured shale. Doust and Omatsola (1990) described a variety of structural trapping elements, including those associated with simple rollover structures clay-filled channels, structures with multiple growth faults, structures with antithetic faults and collapsed crest structures in the Niger Delta. On the flanks of the delta, stratigraphic traps are likely as important as structural traps. In this region, pockets of sandstone occur between diapiric structures. Towards the delta toe (base of distal slope) this alternating sandstoneshale sequence gradually grades to essentially sandstone. The primary seal rock in the Niger delta is the interbedded shale within the Agbada Formation. The shale provides three types of seals-clay smears along faults, interbedded sealing units against which reservoir sands are juxtaposed due to faulting and vertical seals. On the flanks of the delta, major erosional events of early to middle Miocene formed canyons that are now clay-filled. These clays form the top seal for some important offshore field locations. 


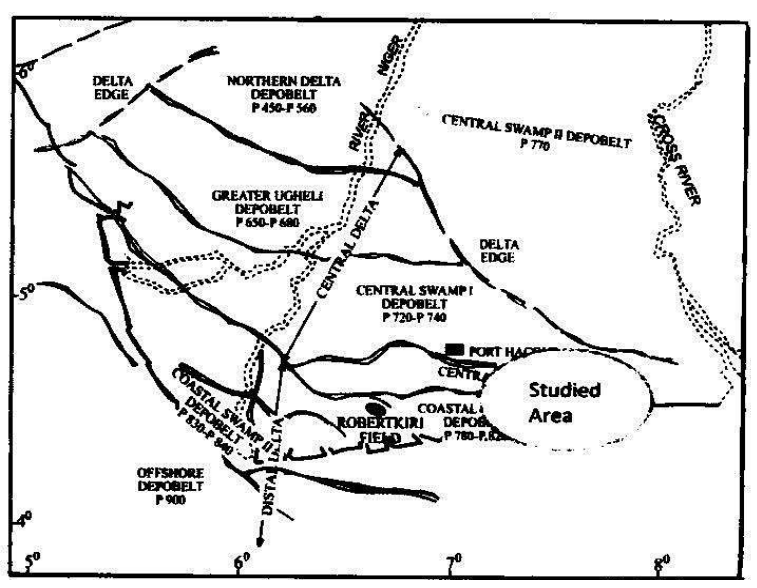

Fig. 1. Map of Niger Delta Showing the Location of the study area

\section{MATERIALS AND METHODS}

Predrill pore pressure can be estimated by appropriate transformation of seismic velocities. This implies that accurate determination of seismic interval velocity is essential for reliable results. The porepressure prediction technique in this work is based on the combination of Dutta $(1997 ; 2002)$ and Bowers (1995; 2002) theories which were developed to transform geologically calibrated seismic interval velocities to pore pressure. The basic data used for this work are seismic sections, checkshot data and suit of geophysical logs obtained for the field in onshore Niger delta. The following procedures were adopted in this research work.

\subsection{Seismic Velocities Determination}

Various methods have been used to determine seismic velocity. In pore pressure prediction only those velocities that are accurate and are close to the formation velocity under consideration are of interest. In this study, layer cake velocity model was used to generate pseudo-interval velocities which are used for the pore pressure analysis. To obtain the pseudo interval velocities, true vertical depth obtained from the well stratigraphy boundaries and the two-way travel times obtained from the same horizons surface in the seismic section were used. Both the geophysical well $\log$ and checkshot data were incorporated into the velocity determination. These values were obtained for the entire stratigrahical intervals picked on the seismic section as delineated in the well. These values were average to obtain the final interval velocities.

\subsection{Determination of Pore Pressure from Seismic Velocity}

Having obtained the seismic velocities, estimates of pore pressure was then made using the method of transforming seismic velocity to pore pressure. This is possible because it was assumed that the elastic wave velocities depend on the pore pressure and the total stress tensor through the relation Equation (1):

$\mathrm{ij}=\mathrm{Sij}-\alpha \mathrm{P} \delta \mathrm{ij}$

Where:

$\delta_{\mathrm{ij}}=1$ if $\mathrm{i}=\mathrm{j}$ and 0 otherwise

$\alpha=$ Coefficient

$\mathrm{P}=$ Pore pressure

$\sigma_{\mathrm{ij}}=$ Effective stress tensor

$\mathrm{S}_{\mathrm{ij}}=$ Total stress tensor

According to Eaton (1975) and Bowers (1995) the value of $\alpha=1$. Denoting the vertical component of the effective stress tensor $\sigma_{\mathrm{ij}}$ by $\sigma$ and the vertical component of the total stress tensor $S_{i j}$ by $S$ then the vertical component may be written as:

$\sigma=\mathrm{S}-\mathrm{P}$

Where:

$\mathrm{P}=$ Pore pressure

$\mathrm{S}=$ Vertical component of the total stress tensor

$\sigma=$ Vertical component of differential stress tensor

If the vertical component of the total stress is known and the seismic velocity has been used to determine the differential stress tensor then the pore pressure can be predicted using the Equation (2).

The value of the overburden pressure (S) at any depth $\mathrm{H}$ is the combined weight of the fluids and formation above $\mathrm{H}$ and it is given as Equation (3):

$\mathrm{S}=\mathrm{H} \rho \mathrm{g}$

Where:

$\mathrm{S}=$ Overburden pressure

$\mathrm{H}=$ Depth

$\rho(z)=$ Density as a function of depth $(z)$

$\mathrm{g}=$ Acceleration due to gravity

Gardner et al. (1974) equation was used for obtaining the formation density from seismic velocity. The relationship between the velocity and density is given as Equation (4):

$\rho=V^{b}$ 
Where:

$\rho=$ Density

$\mathrm{V}=$ Formation velocity

$\alpha=$ Coefficient

$\mathrm{b}=$ Exponent

The Gardner's transform often calculates densities which are too low when the standard values for the coefficient and exponent of 0.23 and 0.25 are used. In the light of this the value of $\alpha$ and $b$ were adjusted by calibrating the relation with available well data obtained from Niger delta.

Bowers (1995) established a relationship between the effective stress and formation velocity in normal pressure sediments which is given as:

$\mathrm{V}=\mathrm{Vo}+\mathrm{A}^{\mathrm{B}}$

Where:

$\mathrm{V}=$ Formation velocity

$\mathrm{V}_{\mathrm{o}}=$ Velocity of unconsolidated fluid saturated sediment (taken to be $1600 \mathrm{~m} \mathrm{sec}^{-1}$ )

$\sigma=$ Vertical component of differential stress (effective pressure)

The coefficient $\mathrm{A}$ and exponent $\mathrm{B}$ describe the variation in velocity with increasing effective stress.

Rewriting Equation (5) above, we obtained:

$\sigma=((\mathrm{V}-\mathrm{Vo}) /(\mathrm{A}))^{\wedge} 1 / \mathrm{B}$

The Bowers normal compaction trend parameters were developed by fitting the Bowers normal compaction trend to known effective stress and seismic velocity. The values of A and B obtained for Niger Delta after correlation with existing data are 4.5641 and 1.461 respectively.

The pore pressure was then calculated from Equation (1) by substituting the computed values of the overburden pressure, $S$ and effective pressure, $\sigma$ in Equation (3 and 6) respectively.

\subsection{Determination of Normal (Hydrostatic) Pressure}

The normal pressure is pore fluid pressure that equals the hydrostatic pressure of a column of formation water extending to the surface. The hydrostatic pressure varies with the density of fluid and height of column but is independent of the shape and size of the column. The prevailing water pressure in the vicinity of a reservoir dictates fluid pressure regimes in the hydrocarbon columns. In a normal case, the pressure at any depth can be calculated as:

$$
\mathrm{P}_{\mathrm{n}}=(\mathrm{dp} / \mathrm{dZ})_{\text {water }} * \mathrm{Z}+14.7(\mathrm{psi})
$$

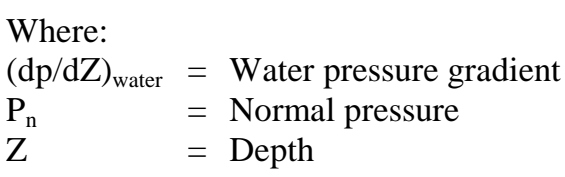

For pure water, the value of water pressure gradient is 0.433 pounds second per feet (psi/ft). The surface pressure of one atmosphere is $14.7 \mathrm{psi}$. When the formation/pore pressure is lower/greater than hydrostatic/normal pressure, underpressure/overpressure will occur.

\section{RESULTS}

The computed interval velocities used in this study were obtained from the seismic section shown in Fig. 2. The seismic section presented here extends to 3.3 seconds two way travel time, below which reflection continuity is generally poor. The seismic section characterized by a series of parallel reflections offset and deformed by major listric normal faults. The character of the seismic record changes with depth. Reflections within the upper region of the section have moderate to good continuity and high amplitude variations.

The computed interval velocities were plotted against depth in Fig. 3. The interval velocity increases progressively downward from $1500 \mathrm{~m} / \mathrm{sat}$ the surface to about $3350 \mathrm{~m} \mathrm{sec}{ }^{-1}$ at a depth of $3500 \mathrm{~m}$ (approximate to $2.855 \mathrm{sec}$ two way time). The interval velocities start decreasing as from the depth of 3500 $\mathrm{m}(11475.11 \mathrm{ft})$. The decrease in velocity may be attributed to increase in porosity due to undercompaction and the associated overpressure.

Figure 4 is a plot of the computed differential effective stress with depth. The differential pressure was computed using Equation (7). The vertical effective stress increases with depth from the surface to about $3500 \mathrm{~m}$ when it starts decreasing with depth. The depth at which it starts decreasing can also be infers as the top of the overpressure zone.

The trend of the computed formation pore-pressure (pore pres), overburden pressure (ov pres), fracture gradient (fract press) and the hydrostatic pressure (nor pres) versus depth for the region is shown in Fig. 5. The hydrostatic and overburden pressures increase linearly with depth. The pore pressure value was computed using Equation (2). The depth at which the pore pressure starts increasing is known as the top of overpressure. The computed fracture pressure from an offset well also increases linearly with depth. 


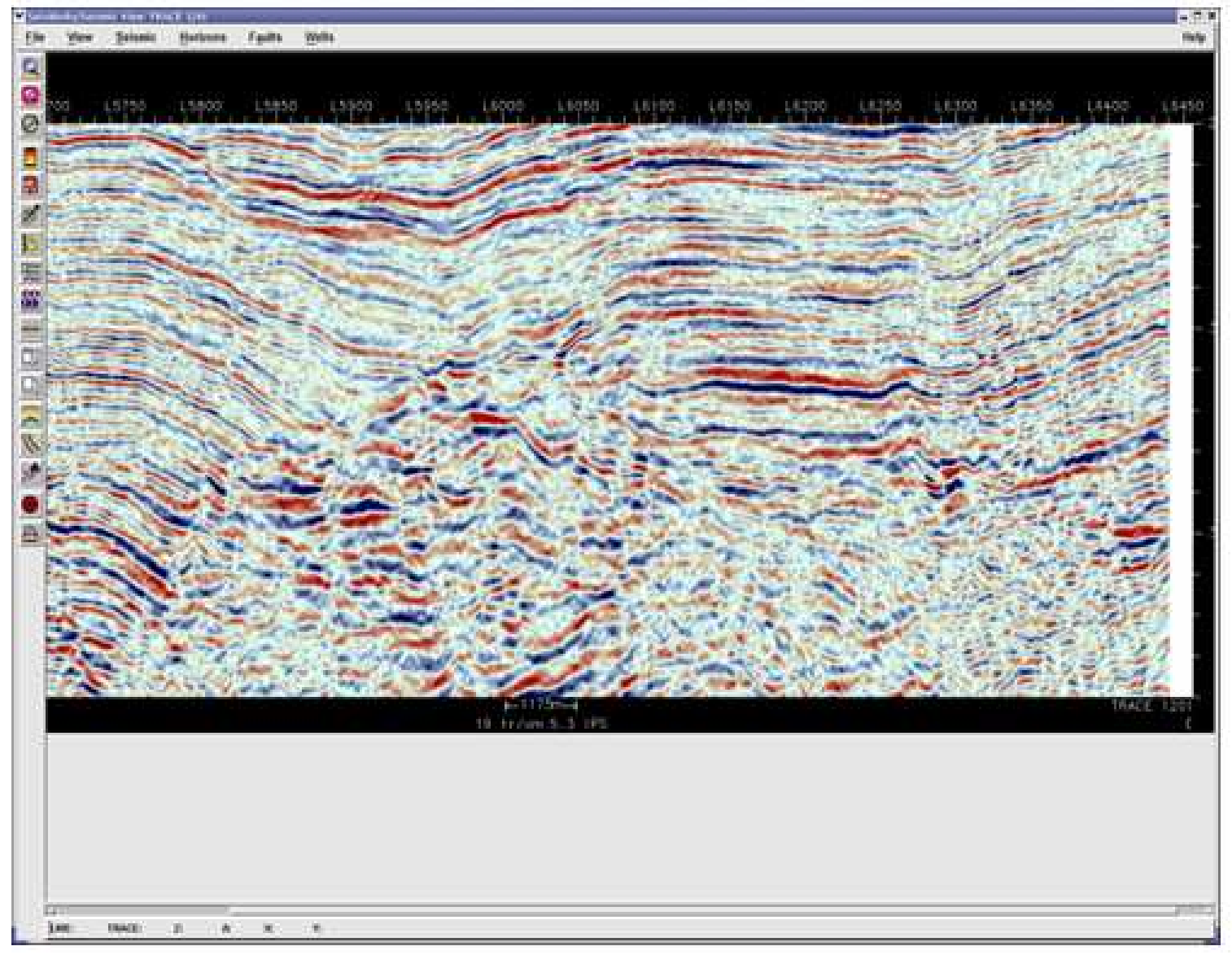

Fig. 2. Seismic section of the study area

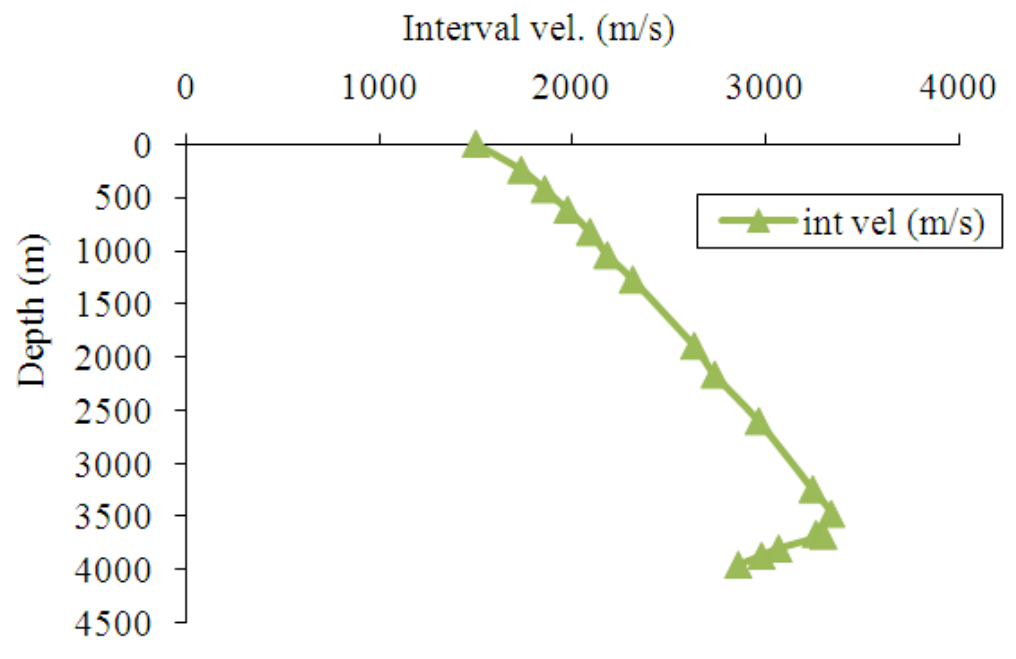

Fig. 3. Plot of velocity versus depth 


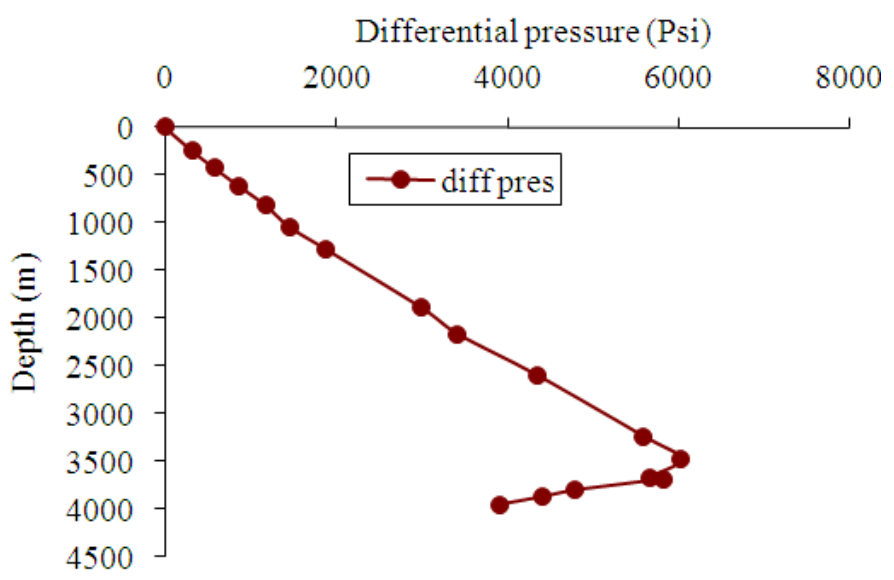

Fig. 4. Plot of differential pressure versus depth

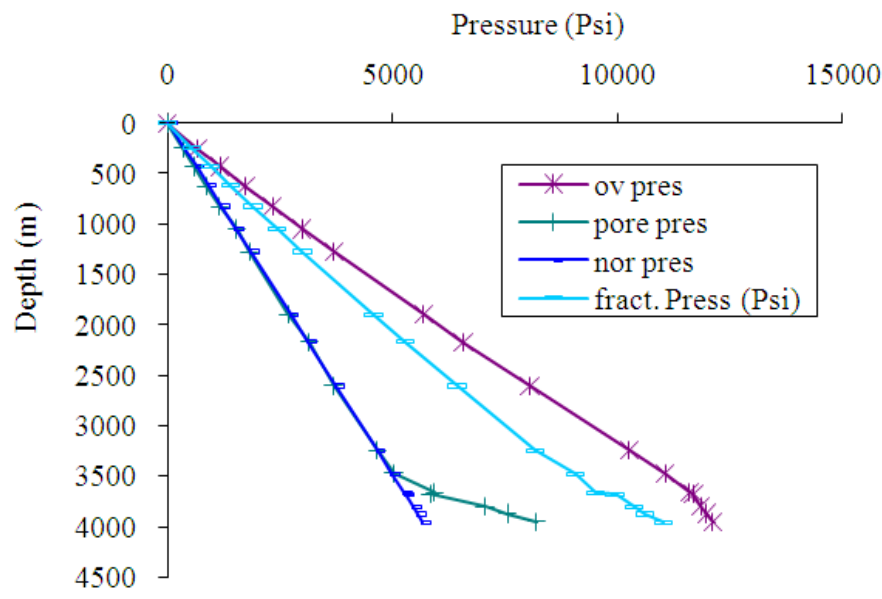

Fig. 5. Plot of pressure versus depth

\section{DISCUSSION}

The interval velocities computed from the seismic data and checkshot data increase with depth from the surface to $3500 \mathrm{~m}$ and start decreasing. Of interest in this work is the depth (approximately above $3500 \mathrm{~m}$ or 2.855 sec two way time) where the velocity start decreasing. The computed overburden and hydrostatic pressures increased with depth from the surface downward. This is as a result of increase in depth and density.

With reference to Fig. 6 the pore pressure values tie with the hydrostatic pressure from the earth surface till a depth of about $3500 \mathrm{~m}$. This may be attributed to normal compaction and increase in velocity with depth. Above the depth of $3500 \mathrm{~m}$, the pore pressure starts to increase abnormally and deviate from the hydrostatic trend. The increase in pore pressure may be as a result of increased in porosity due to low density, under-compaction and hydraulic fractures.

The computed effective stress which increases with depth from the surface starts decreasing from the depth of about $3500 \mathrm{~m}$. This decrease in shear stress may be as a result of overpressure. The implication is that the pore fluid is sustaining most of the vertical load (stress).

Comparison of the depth of over pressure zone with the available suite of geophysical logs from borehole within the field show good agreement. The geophysical $\operatorname{logs}$ are resistivity, density and neutron. The resistivity and density values decrease slightly with depth above the $3500 \mathrm{~m}$ (11475.40ft) while the neutron $\log$ value shows an increase. These geophysical logs are normally used for pore pressure prediction. The good correlation shows that the seismic velocity has sufficient sensitivity to pore pressure prediction. 


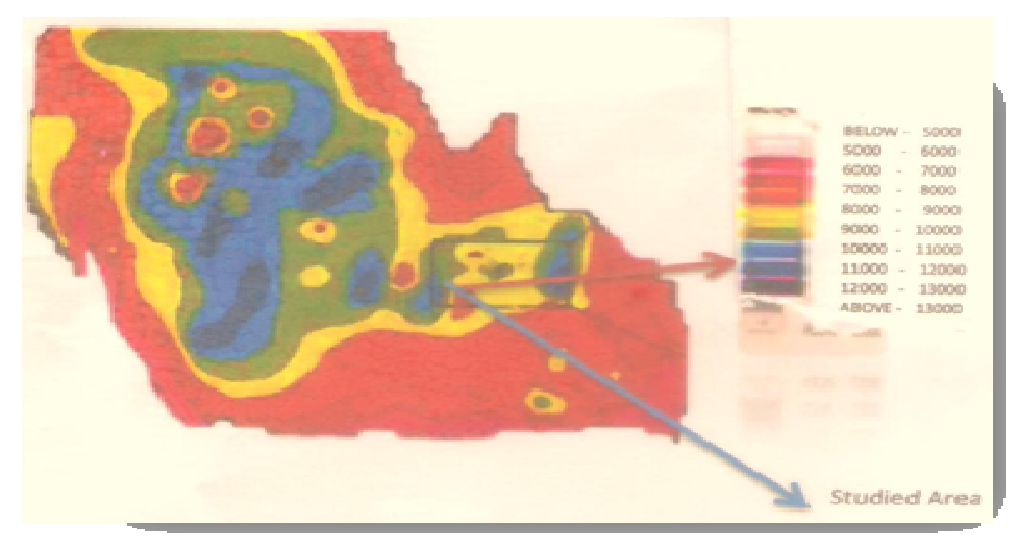

Fig. 6. Map of the Niger delta showing depth-to-Top of overpressure zones (modified from Benjamin and Nwanchukwu, 2011)

The results of this research was also compared with previous ones (Uko et al., 2013; Cobbold et al., 2009; Owalabi et al., 1990; Omolaiye et al., 2011; Osinomo et al., 2007) in the Niger Delta. The various results confirmed the present of overpressure in the sedimentary basin. Although the depth of the onset and values of overpressure were slightly different as a result of the studied area and the techniques used, yet they all confirmed overpressure zones within the Niger Delta.

The location of the study area on a map of the distribution of the depth-to-top of overpressure zones in the Niger Delta (Fig. 6) further show that the overpressure zones start from the depth of about $3500 \mathrm{~m}$.

High pore pressures are typically found in young rapidly deposited clastic rock because of incomplete dewatering of the fine-grained rocks such as shales. The amount of overpressure is a function of the permeability of the rocks and the rate of burial. Therefore, the overpressure observed in the study area may be attributed to sediment burial, temperature and sediment permeability. Areas of high sedimentation rate normally correlate along continental margins. Tertiary delta normally exhibit a high sand content on the shelf and delta top leading to near normal pressure conditions down to the depth of $3000 \mathrm{~m}$, below which a sharp increase in overpressure leads to several drilling challenges. Furthermore, seaward down to the continental slope, the sediments become more mud rich. Results of the data analysis also revealed that overpressures in the area are associated with simple rollover structures bounded by growth faults, especially at the hanging walls. The Niger Delta contains thin skinned structures, including forethrusts, back-thrusts and folds. They detach on flatlying faults within the Akata Formation. The surfaces slopes and apical angles of the thrust wedges are small, indicating a small resistance to basal slip due to gravity instability. This implies high values of fluid overpressure at the basal detachment.

\section{CONCLUSION}

Seismic interval velocity- pore pressure transform has been derived for part of Onshore Niger Delta Sedimentary basin. Determination of pre-drill overpressure zones can be achieved by establishing an accurate seismic velocity-pore pressure transform. The result of the analysis shows that the depth to the top of overpressure zone in the area is about $3500 \mathrm{~m}$. The overpressure zone in the subsurface may be attributed to under compaction of the shale lithologies in the basal Agbada and top of Akata Formations. This under compaction is responsible for the presence of low density, low velocity, high porosity, fault system and fractures in the subsurface (especially at the base of the Agbada Formation). Results of the data analysis revealed that overpressures in the area are associated with simple rollover structures bounded by growth faults, especially at the hanging walls. The Niger Delta contains thin skinned structures, including forethrusts, back-thrusts and folds. They detach on flatlying faults within the Akata Formation. The surfaces slopes and apical angles of the thrust wedges are small, indicating a small resistance to basal slip due to 
gravity instability. This implies high values of fluid overpressure at the basal detachment.

\section{REFERENCES}

Bell, S., 1994. HPHT wells present safety, cost control challenges. J. Petroleum Engineer Int., 66: 1-54.

Benjamin, U.K. and J.I. Nwachukwu, 2011. Model compaction equation for hydrostactic sandstones of the Niger delta. J. Sci., 13: 161-174.

Bowers, G.L., 1995. Pore pressure estimation from velocity data: Accounting for overpressure mechanisms besides undercompaction. SPE Drill. Complet., 10: 89-95. DOI: 10.2118/27488-PA

Bowers, G.L., 2002. Detecting high overpressure. Lead. Edge, 21: 174-177. DOI: 10.1190/1.1452608

Carcione, J.M. and F. Cavallini, 2002. Poisson's ratio at high pore pressure. Geophys. Prospect., 50: 97-106. DOI: 10.1046/j.1365-2478.2002.00299.x

Cobbold, P.R., B.J. Carke and H. Loseth, 2009. Structural consequences of fluid overpressure and seepage forces in the outer thrust belt of the Niger Delta. Petroleum Geosci., 15: 3-15. DOI: 101.1144/1354-079309-784

Doust, H. and E. Omatsola, 1990. Niger Delta. In: Divergent Passive Margin Basins Tulsa, Edwards, J.O. and P.A. Santogross (Eds.), AAPG Memoir, pp: 201-238.

Dutta, N., 2002. Geopressure prediction using seismic data: Current status and the road ahead. Geophysics, 67: 2012-2041. DOI: 10.1190/1.1527101

Dutta, N.C., 1997. Pressure prediction from seismic data: implications for seal distribution and hydrocarbon exploration and exploitation in the deepwater gulf of Mexico. Norwegian Petroleum Soc. Special Publicat., 7: 187-199. DOI: 10.1016/S0928-8937(97)80016-1

Eaton, B.A., 1975. The Equation for Geopressure Prediction from Well Logs: Society of Professional Engineers.

Evamy, D.D., J. Harcmboure, P. Karmmerling, W.A. Kossp and F.A. Molloy et al., 1978. Hydrocarbon habitat of Tertiary Niger Delta. AAGP Bull., 62: 1-39.

Gardner, G.H.F., L.W. Gardner and A.R. Gregory, 1974. Formation velocity and density-the diagnostic basis for stratigraphic traps. Geophysics, 39: 2085-2095. DOI: $10.1190 / 1.1440465$

Huffman, A.R., 2002a. The Future of Pressure Prediction using Geophysical Methods. In: Pressure Regimes in Sedimentary Basins and their Prediction: AAPG Memoir, Huffman, A.R. and G.L. Bowers (Eds.)., AAPG, Tulsa, ISBN-10: 0891813578, pp: 217-233.
Huffman, A.R., 2002b. The future of pore pressure prediction using geophysical methods. Lead. Edge, 21: 199-205. DOI: 10.1190/1.1452613

Ige, O.E., K. Datta, K. Sahai and K.K. Rawat, 2011. Palynological studies of sediments from north Chioma-3 well, Niger Delta and its palaeoenvironmental interpretations. Am. J. Applied Sci., $\quad 8$ : 1249-1257. DOI: 10.3844/ajassp.2011.1249.1257

Kulke, H., 1995. Regional Petroleum Geology of the World Part 11: Africa, American. 1st Edn., Berlin Gebruder Bornbraeger, Australia and Antarctica.

O'Connor, S., R. Swarbrick, B. Pindar, O. Lucas and F. Adesanya et al., 2011. Pore pressure prediction in the Niger Delta-Lessons learnt from regional analysis. NAPE, Lagos Nigeria.

Omolaiye, G.E., J.S. Ojo, M.I. Oladapo and E.A. Ayolabi, 2011. Overpressure prediction of the Efomeh field using synthetic data, onshore Niger Delta, Nigeria. Explorat. Geophys., 42: 50-57. DOI: 10.1071/EG09040

Opara, I.A and M.K. Onuoha, 2009. Pre-drill pore pressure prediction from 3-d seismic data in parts of the onshore Niger delta basin soc. Proceedings of the Nigeria Annual International Conference and Exhibition, (NAICE' 09).

Osinomo, O.O., M.A. Oladunjoye and A.I. Olayinka, 2007. Overpressure prediction from seismic data: Implications on drilling safety. American Geophysical Union, Fall Meeting.

Owalabi, O.O., G.A. Okpobiri and I.A. Obomanu, 1990. Prediction of abnormal pressure in the Niger Delta using well logs. Proceedings of the CIM/SPE International Technical Meeting, (ITM' 90), Calgary, Canada.

Short, K.C. and A.J. Stauble, 1967. Outline of geology of Niger delta. AAPG Bull., 51: 761-799.

Stacher, P., 1995. Present Understanding of the Niger Delta Hydrocarbon Habitat. In: Geology of Deltas: FRotterdam, Bakkema, A.A., M.N. Oti and G. Postma (Eds.), pp: 57-267.

Uko, E.D., J.E. Emudianughe and I. Tamunobereton-ari, 2013. Overpressure prediction in the north-west niger delta, using porosity data. J. Applied Geol. Geophys., 1: 42-50.

Whiteman, A., 1982. Nigeria: Its geology, resources and potential: London. Graham Trotman., 2: 25-276. 